\title{
Climate change effects on grasslands in Uruguay
}

\author{
Daniel Panario ${ }^{1, *}$, Mario Bidegain ${ }^{2}$ \\ ${ }^{1}$ Unidad de Ciencias de la Epigénesis and ${ }^{2}$ Departamento de Meteorología, Facultad de Ciencias, \\ Universidad de la República, Tristán Narvaja 1674, Montevideo, Uruguay
}

\begin{abstract}
The most significant climax vegetation in Uruguay is a type of grassland commonly known as evergreen prairie. The evolution of the Uruguayan prairie since the days of the first European settlements involved 3 main stages: (1) 'hardening' as a result of the introduction of livestock, (2) 'refinement' by the action of fire and overgrazing, and (3) further degradation, including preferential development of warm-season species, due to persistent overgrazing. Predicted climate changes (seasonal decrease in water availability coupled with increase in both temperature and atmospheric $\mathrm{CO}_{2}$ concentration) are likely to favor, in the short term, even further preferential development of warm-season species. Whether or not this trend will persist in the long term is difficult to predict with confidence because of uncertainties regarding the responses of the different prairie species to variation in atmospheric $\mathrm{CO}_{2}$ concentration.
\end{abstract}

KEY WORDS: Grasslands · Climate change · Uruguay

\section{INTRODUCTION}

Uruguay lies within the Southern Hemisphere midlatitude zone. The predominant climate is of the type Cia (temperate, humid, with no dry season) according to the Köppen classification. The most important climax vegetation is an evergreen grassland which, according to the available historical information, is characterized in its natural state by tall grasses in most of the territory.

The rainfall pattern of Uruguay, characterized by mean annual values of $1200 \mathrm{~mm}$ homogeneously distributed throughout the year, is related to forest vegetation throughout the world. Various hypotheses have been proposed to explain why woods in Uruguay exist only along rivers and streams as well as in some hilly areas. The most plausible one refers to a combination of various factors:

- Most soils in Uruguay are saturated, with a high content of lime and/or clay, which are considered limiting factors for the development of woods. Nevertheless, native woods grow at some sites in the country on

\footnotetext{
•E-mail: panari@fcien.edu.uy
}

soils with either high clay or lime content. In contrast, the grassland is the climax vegetation of leached sandy soils.

- The abundance of thin soils, the relatively low topography and the occurrence of high mean wind speeds ( 3.5 to $4 \mathrm{~m} \mathrm{~s}^{-1}$ ) are the reason for the actual water availability being lower than in other regions having a similar precipitation pattern.

This study, based on both empirical field analyses and a thorough literature review, examines the conditions to which the grasslands would be subject under a new environmental scenario derived from a potential climate change (increase in temperature and different distribution of precipitation throughout the year).

\section{METHODOLOGY}

The information used was obtained from field studies on natural pastures carried out at the Facultad de Agronomia of the Universidad de la República and, more recently, at the Dirección de Suelos y Aguas of the Ministerio de Ganadería, Agricultura y Pesca. Results from these studies indicate that, as regards soil conditions, the current plant species composition in the 
grasslands is strongly influenced by field management practices

The climate change scenarios for the South American southeastern region were derived from general circulation model outputs reported by R. Hofstadter and M. Bidegain (pers. comm.). The models considered were: GFDL (Geophysical Fluid Dynamics Laboratory), UKMO (United Kingdom Meteorological Office) and GISS (Goddard Institute for Space Science).

\section{RESULTS AND DISCUSSION}

\subsection{Evolution of the native grassland}

On the basis of the information above and available historical data, the evolution of the grass cover can be summarized as occurring in 3 stages. However, conditions of all 3 stages have coexisted in different proportions up to the present.

\subsubsection{First stage}

The first stage comprises the grassland changes subsequent to the introduction of livestock, up until fields are fenced.

This stage consists of grassland hardening characterized by the substitution of the most productive species for others with more lignin.

It is assumed that burning of overmature grasses either has occurred as a natural process or has been carried out by the natives for hunting purposes.

Farmers have observed that pastures in this stage which have turned 'hard' as a result of summer undergrazing have become 'tender' as a consequence of post-burning sprouting. Areas which have been managed in this way are then overgrazed during hard winter times. The less affected species are those having their reservoirs close to the ground or even underground, such as rhizomatous and stoloniferous species, the tussock and the annual species whose cycle has been completed by the time burning and subsequent overgrazing take place

Thus, in large fields, burning and alternating overgrazing and selective grazing have resulted in grassland hardening and increased development of species such as Stipa charruand, Paspalum quadrifarium and Andropogon lateralis.

It is assumed that a species originates from the most limiting environment out of those where it vigorously grows, and that it behaves as an intruder in other less limiting environments. Based on this assumption, xeromorphic hard plants such as Stipa charruana would be climax species on very fertile shallow soils developed on a limestone horizon, namely 'Litosoles Eutricos' (Lithic Udorthent) (Altamirano et al. 1976) as well as in shallow very limy phases of some southern 'Vertisoles' (Typic Pelludert). Thus, Paspalum quadrifarium would be a climax species in shallow or moderately shallow soils on crystalline rock of the 'Brunosol Subéutrico' type (Typic Argiudoll) and would behave as an intruder when niches having less limiting conditions become available.

These species are likely to be among the earliest to occupy niches released by the best pastures of the prairie. However, even though these species are hard and rough, they have a large root biomass and produce residues. Those characteristics have contributed to supporting soil biological activity and keeping nutrients easily available (a condition produced by the overstock of organic matter and its mineralization).

Obviously, these 'xerophytic' species do not represent the climax vegetation of fertile soils with high water availability, where non-xeromorphic and larger species grow successfully. Therefore, it has been observed that during this stage a hardening of the prairie takes place. This process lasts until fields are fenced and later subdivided.

\subsubsection{Second stage}

Under the previously mentioned conditions, a change in the prairie, known as grassland 'refinement' is induced by the destruction of common species through fire and/or overgrazing. The consequent accumulation of energy and nutrients in the soil and the new release of niches induce the covering of subdivided fields by tender intruder species having secondary productivity probably lower than the climax species, but higher than those previously established. These include annual exotic species such as Lolium multiflorum (ryegrass) and other interstitial species. However, only the caespitose species may be considered as climax species in the deep soils of this region.

Apparently the Uruguayan native grasslands, long adapted to grazing, have evolved by reducing their height. Most of the grasses which currently compose this system are creepers. This habit is modified when the grasses are no longer subject to livestock grazing. This was observed by Rosengurtt (Gallinal et al. 1938) based on studies in the Palleros area.

The development of short grasses is therefore a means of resistance by the grassland, where hard grasses and intruder weeds grow as a result of overgrazing, particularly by sheep (Gallinal et al. 1938).

This second stage is thus characterized by an overabundance of annual species during winter, combined 
with perennial warm-season species (mainly C4 such as different Paspalum spp.).

\subsubsection{Third stage}

The persistence of overgrazing during fall and winter (particularly as a result of the introduction of sheep) by an often excessive number of animals induces the third stage of prairie regression.

Studies carried out by May \& Panario (1995) and May et al. (1990) have confirmed that these usage practices have led, in the medium term, to the development of weeds such as Eryngium horridum and Bacharis, as well as small rosette-like weeds and other low-productivity species such as Bothriochloa.

The perennial cool-season species are the most affected by the traditional usage practices, since they are the first to sprout after the forage crisis of the winter season. The loss of soil biological productivity causes the reduction of the most productive and palatable annual grasses such as Bromus catharticus and even ryegrass, as well as of highly productive summer species such as Paspalum dilalatum. Therefore, this stage is characterized by the development of weeds consisting of shrubs, small or common annual cool-season grasses, and warm-season rhizomatous or stoloniferous grasses. Some of these species, such as Paspalum notatum and Axonopus sp., have a considerable value as forage.

If pressure continues to increase, the best-growing warm-season species (e.g. Paspalum notatum, $P$. dilatatum and Axonopus sp.) will be replaced by rougher species such as Cynodon dactylon or even by the above-mentioned rosette-like weeds and shrubs. This will induce a situation almost unknown in the non-agricultural areas of the country, representing a fourth stage of regression.

This hypothesis is confirmed by studies carried out in field plots incidentally excluded from grazing for 5- to 20 -yr periods, where a smaller number of species than predicted by Rosengurtt predominate (May \& Panario 1995). A progressive decrease of the smaller weeds, even of Bacharis coridifolia, was observed in those cases. A progressive increase of cool-season species was observed on fertile shallow soils which had developed on basalt, representing up to $50 \%$ of the canopy after a relatively long period (approximately 20 yr).

On deep soils, almost complete dominance of the productive cool-season Stipa setigera species may be observed within a much shorter exclusion period ( 7 to $10 \mathrm{yr}$ ). The awnless are clearly predominant over the pubescent varieties, which contrasts with the situation of some plants of this species found in neighboring grazed fields (May \& Panario 1995). It should be pointed out that pubescence is considered a xeromorphic characteristic.

Grazed fields experience few modifications, as confirmed by results from studies by May et al. (1990) at the same sites studied by Rosengurtt in the 1930s (Gallinal et al. 1938). This may indicate that they have attained a relative equilibrium with grazing pressure, although the proportion of plant species other than grasses has increased.

Assuming that these results can be extrapolated to fields which are not subject to severe pressure by sheep, it could be inferred that the natural grassland degradation process has reached a relative equilibrium as to plant species composition. However, this is not the case with regard to soil conservation.

In leached soils the climax grassland is typically composed of warm-season species. Therefore, changes caused by the impacts of usage practices are likely to have been less dramatic in those areas.

\subsection{Potential effects of climate change on grasslands}

The potential impact of an increase in the atmospheric concentration of $\mathrm{CO}_{2}$ on this region is still uncertain. Results from general circulation model simulations ( $R$. Hofstadter \& M. Bidegain pers. comm.j project different precipitation patterns associated with an increase in temperature of $0.3^{\circ} \mathrm{C}$ per decade and the corresponding evapotranspiration increase.

The analysis of precipitation variations in Uruguay during the 1961 to 1990 period indicates that the mean annual value has increased by $200 \mathrm{~mm}$, with a shift in the maxima from the northeast towards the southwest (Bidegain \& Deshayes 1992).

Temperature records for the past $30 \mathrm{yr}$ indicate an increase of approximately $1^{\circ} \mathrm{C}$ in summer values, with no significant changes in the remaining seasons.

Studies on the Quaternary carried out mostly for the pampean region, and to a lesser extent for Uruguay, show a relationship between an increase in temperature and more humid conditions, although the abundance of smectites in the sediments is evidence of the occurrence of some dry periods. In contrast, a decrease in precipitation has been associated with periods of lower temperatures (Politis 1984, Prost 1984, Panario 1987). The continental regions more distant from the oceanic coast are subject to the highest increase in temperature during the warm season.

Based on this, a precipitation increase in the western and northern sectors of the country is likely to occur, as well as a decrease in winter precipitation. This would result in an even higher pressure on the cool-season varieties. 
The warm-season varieties, particularly $\mathrm{C} 4$ (which require high temperatures for initiating spring development) would start growing once the impact of the winter forage crisis has been reduced as a result of the growth of annual and cool-season varieties. Should the increase in $\mathrm{CO}_{2}$ be moderate, warm-season varieties, which are favored by both the usage practices and the increase in temperature, would become dominant even in areas where the climax vegetation is typically composed of cool-season species.

It is also foreseen that $\mathrm{C} 3$ varieties, which are more resistant to an increase in the $\mathrm{CO}_{2}$ levels and are adapted to lower temperatures (Parry et al. 1992), would be less affected in the southern and southeastern regions, where the increase in temperature is likely to be lower.

\section{LITERATURE CITED}

Altamirano A, da Silva H, Durán A, Echevarría A, Panario D, Puentes R (1976) Carta de reconocimiento de suelos del Uruguay, Tomo I, Clasificaión de suelo. Dirección de Suelos y Fertilizantes, Ministerio de Agricultura y Pesca, Montevideo

Bidegain M, Deshayes C (1992) Variabilidad climática secular de la precipitación en Uruguay. In: Anales del I Congreso Iberoamericano de Meteorología y $\mathrm{V}$ Congreso Inter- americano de Meteorología, Salamanca, España. AME, Madrid, p 39-43

Gallinal JP, Bergalli LU, Campal EF, Aragone L, Rosengurtt B (1938) Estudios sobre praderas naturales del Uruguay: primera contribución. Imprenta Germano-Uruguaya, Montevideo

May H, Di Landro E, Alvarez C (1990) Avances en la caracterización de sitios en el estudio integrado de pasturas naturales y suelos en la Estancia Palleros. In: Anales del II Seminario Nacional de Campo Natural. Editorial Hemisferio Sur, Montevideo, p 11-33

May H, Panario D (1995) Estudio comparativo de la sucesión ecológica de la flora pratense en dos sitios de la región basáltica, suelo superficial y suelo profundo en condiciones de exclusión y pastoreo. In: Boletín Técnico No. 13, Dirección de Suelos, Ministerio de Ganadería, Agricultura y Pesca, Montevideo, p 55-77

Panario D (1987) Geomorfología. Propuesta de un marco estructural y un esquema de evolución del modelado del relieve uruguayo. Serie Avances de Investigación, Facultad de Humanidades y Ciencias, Universidad de la República, Montevideo

Parry ML, Mendzhulin GV, Sinha S (1992) Agricultura y silvicultura. In: Cambio climático. Evaluación de los impactos del IPCC, Chap 2. OMM/PNUMA, Montevideo, p 29-79

Politis G (1984) Climatic variations during historical times in Eastern Buenos Aires Pampas, Argentina. In: Rabassa J (ed) Quaternary of South America and Antarctic Peninsula. 2:133-161

Prost MT (1984) Heritages quaternaires et evolution geomorphologique des bords du Río de la Plata en Uruguay. Thèse de Doctorat en Geomorphologie, Paris VII-Jussie 